\title{
Relationship Of Nurse's Knowledge About Schizophrenia With The Care Of Schhizoprenia Patients In The Regional General Services Agency Of Aceh Mental Hospital Banda Aceh
}

\section{Yenikha Gea Arafa}

Faculty Of Nursing, University Of North Sumatra, Jl. Dr. Mansur No. 9, Padan Bulan, Kec. Medan Baru, Kota Medan, 20222

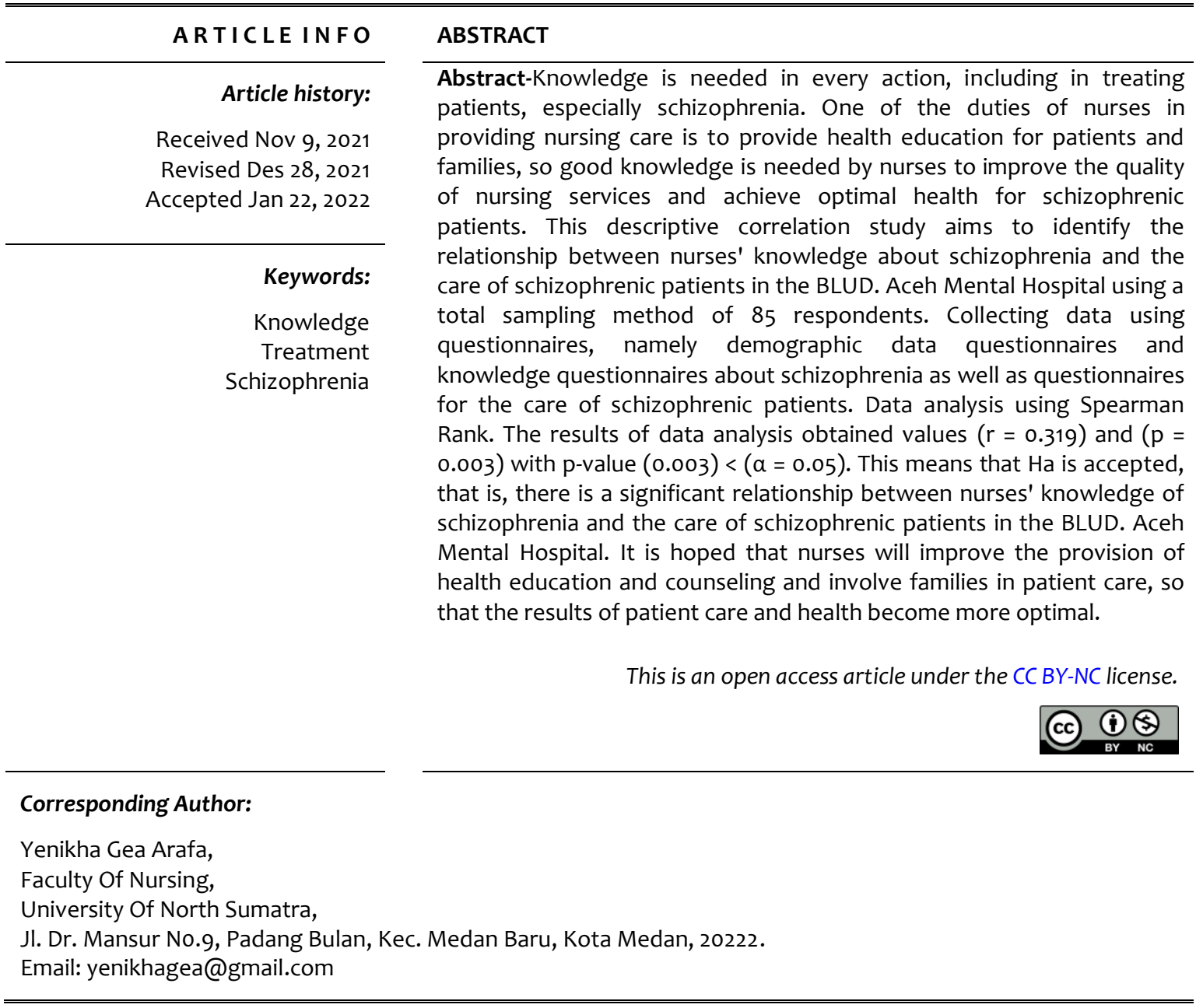

\section{Introduction}

Health is not only measured by physical condition, but also mental and social health so that a person can live economically and productively (Notoatmodjo, 2005). Mental disorders are maladaptive responses to stressors from the internal or external environment, evidenced by thoughts, feelings, and behaviors that are not in accordance with local norms or local culture and interfere with social, work and or physical functions (Depkes RI 2003). According to the World Health Organization (WHO, 2001) the problem of mental health disorders throughout the world has indeed become a very serious problem, at least one in four people in the world experience mental problems. 
One form of mental disorder that is found throughout the world is a severe mental disorder, namely schizophrenia (Hawari, 2007). According to Yarusman (2007), schizophrenia is a serious mental disorder characterized by loss of contact with reality (psychosis), hallucinations, delusions (false beliefs), abnormal thoughts and interfere with work and social functioning.

according to Based on research data, in Indonesia there are about 1-2\% of the population who suffer from schizophrenia (Irmansyah, 2006). If the population of Indonesia is around 200 million people, it is estimated that around 2 million people experience schizophrenia (Arif, 2006). The prevalence of people with schizophrenia in Indonesia is $0.3-1 \%$ and is usually experienced at the age of 18-45 years, and some who are only 11-12 years old have had schizophrenia. Schizophrenia generally begins to be experienced in the age range of 16-30 years and rarely begins above 35 years (Mueser \& Gingerich, 2006). This is in accordance with Sukandar's statement that on average every day, residents who check themselves to the mental disorders section reach 30-40 people, this number continues to increase every year around 3$5 \%$, with the majority being among the productive age (Hidayatullah, 2005). ). Other than that,

The Ministry of Health's 2007 Basic Health Research showed that sufferers of severe mental disorders in Indonesia reached 0.46 percent or about 1 million people. The highest prevalence is in DKI Jakarta (2.03 percent), Aceh (1.9 percent), and West Sumatra (1.6 percent). From the results of the BLUD medical record. Aceh Mental Hospital, Banda Aceh, data obtained in 2012 schizophrenic patients who were hospitalized 12,606 people, and were hospitalized in 1974. In 2013 patients who underwent outpatient 9526 people, and 1520 people were hospitalized.

Usually families who have family members who suffer from schizophrenia will completely surrender care and treatment to mental hospitals because they do not know how to treat people with schizophrenia and they believe that by undergoing treatment in a mental hospital, patients will receive appropriate care and treatment so that the possibility to recover is very large (Arif, 2006). Generally, families seek the help of health professionals if they are no longer able to care for a family member who suffers from schizophrenia. Therefore, nursing care that focuses on the family does not only restore the patient's condition, but aims to develop and improve the family's ability to cope with health in the family. However,

Lack of adequate care in schizophrenic patients is seen in the high rate of relapse of schizophrenia, and the lack of family involvement in schizophrenia care. Given that one of the actions of nursing care is the provision of information or health education to patients and families, the knowledge of nurses in providing nursing care is needed. This is in accordance with the opinion of Basford (2006) which states that knowledge is an important aspect in nursing. Everything a nurse does must be based on knowledge embodied in nursing practice. From the results of research conducted by Nurul Azizatunnisa \& Suhartini (2012) it was found that the description of nurses' knowledge at the Indonesian Holistic Tourist Hospital Purwakarta, West Java about holistic nursing mostly in the sufficient category, namely $69.2 \%$, the remaining $23.1 \%$ of respondents respectively in the high and low categories. From these descriptions, the authors are interested in examining the relationship between nurses' knowledge of schizophrenia and the care of schizophrenic patients in the BLUD. Aceh Mental Hospital, Banda Aceh.

\section{Method}

The design used in this study is descriptive correlation which aims to identify the relationship between nurses' knowledge about schizophrenia and the care of schizophrenic patients in the BLUD. Aceh Mental Hospital, Banda Aceh.

To obtain information from the respondents, the researcher used research instruments in the form of a knowledge questionnaire adopted from the thesis of Erica Ari Uli Purba and a schizophrenia treatment questionnaire which was prepared by the researcher himself based on the literature review and concepts. The instrument in this study consisted of 2 parts, namely a demographic data questionnaire, and a questionnaire on knowledge of nurses and schizophrenia care.

Data analysis is carried out after all data has been collected through several stages starting from editing to check the completeness of the data and making sure all answers have been filled in, then 
coding (coding) to facilitate tabulation. Furthermore, data entry into the computer and data processing is carried out using the SPSS program.

After performing computerized techniques on the data, followed by univariate and bivariate analysis. Univariate analysis is a procedure performed to analyze data from variables that aims to describe a research result (Polit \& Hungger, 1995). In this study, univariate data analysis will be used to analyze demographic data, the independent variable is the knowledge of nurses, and the dependent variable is the care of schizophrenic patients.

The bivariate correlation test, according to Santoso (2001), is used to measure whether or not the relationship is strong between observations from a population that has two variants (bivariate). Strong or not the relationship can be measured by a value called the value of the correlation coefficient. Statistical analysis used in this study is the Spearman Rank statistical test.

\section{Analysis And Results}

\subsection{Nurse's knowledge about schizophrenia}

Of the 85 nurses who became respondents, there were 75 nurses (88.2\%) who had knowledge about schizophrenia and 10 (11.8\%) who had sufficient knowledge about schizophrenia. In this study, there were no nurses who had less knowledge about schizophrenia. The majority of nurses have knowledge in a good category. We can see this in table 1

Table 1

Distribution of Frequency and Percentage of Nurses' Knowledge About Schizophrenia (N=85)

\begin{tabular}{|c|c|c|}
\hline Nurse knowledge & Frequency $(f)$ & Percentage (\%) \\
\hline -Well & 75 & 88.2 \\
\hline -Enough & 10 & 11.8 \\
\hline -Not enough & 0 & 0 \\
\hline Total & 85 & 100.0 \\
\hline
\end{tabular}

\section{a. Treatment of Schizophrenic Patients in the BLUD. Aceh Mental Hospital Banda Aceh.}

After conducting research and data processing, the frequency and percentage of treatment for schizophrenia patients in the BLUD were obtained. Aceh Mental Hospital in good category as many as 59 people (69.4\%) and treatment of schizophrenia patients with sufficient category as many as 26 people (30.6\%). And there is no treatment with a bad category. (Table 2)

Table 2

Distribution of Treatment Frequency for Schizophrenic Patients in BLUD. Aceh Mental Hospital Banda Aceh (N=85)

\begin{tabular}{lccc}
\hline & Schizophrenic Patient Care & Frequency (f) & Percentage (\%) \\
\hline -Well & & 59 & 69.4 \\
-Enough & & 26 & 30.6 \\
-Bad & Total & 0 & 0 \\
& & 85 & 100.0 \\
\hline
\end{tabular}

b. The Relationship between Nurse's Knowledge About Schizophrenia and Treatment of Schizophrenic Patients.

Computerized statistical analysis to identify the relationship between nurses' knowledge about schizophrenia and the care of schizophrenic patients in the BLUD. Aceh Mental Hospital Banda Aceh, using the spearman rank correlation formula, the correlation value is obtained: 
Table 3

The Relationship Between Nurse's Knowledge About Schizophrenia

\begin{tabular}{lcc}
\hline & $r$ & $p$ \\
\hline Nurse's knowledge about schizophrenia & 0.319 & 0.003 \\
Treatment of schizophrenic patients & 0.319 & 0.003 \\
\hline
\end{tabular}

The results of the analysis show that there is a significant relationship between nurses' knowledge about schizophrenia and the care of schizophrenic patients with p-value $(0.003)<(0.05)$ this means Ha is accepted, which means there is a significant relationship between nurses' knowledge about schizophrenia and the care of schizophrenic patients. in BLUD. Aceh Mental Hospital, Banda Aceh.

\subsection{The relationship between nurses' knowledge of schizophrenia and the care of schizophrenic patients in the BLUD. Aceh Mental Hospital Banda Aceh.}

Based on statistical test analysis of the relationship between nurses' knowledge about schizophrenia and the care of schizophrenic patients in the BLUD. Aceh Mental Hospital Banda Aceh obtained p-value $(0.003)<(0.05)$ this means $\mathrm{Ha}$ is accepted. So it can be concluded that there is a relationship between nurses' knowledge about schizophrenia and the care of schizophrenic patients in the BLUD. Aceh Mental Hospital Banda Aceh.

This is in accordance with research conducted by Sri Paryanti (2007) that there is a significant relationship between the level of knowledge of nurses and the skills to carry out hospital procedures. The results of this study indicate that the higher the level of knowledge of nurses, the better the implementation of action procedures by nurses. The results of this study are also in accordance with research conducted by Virgianti (2009) which states that there is a relationship between the knowledge of nurses and the role of nurses as implementers in handling patients. In accordance with several theories put forward by experts, namely the higher the level of knowledge, the better in carrying out nursing interventions (Arikunto, 1993). Meanwhile, according to Notoadmodjo,

Based on this concept, the results of this study are in accordance with the opinions of several experts regarding the relationship between knowledge and nursing care or nursing care actions performed by nurses. So it can be concluded that the better the level of knowledge of nurses, the better in providing nursing care for patients.

\section{Conclusion}

The characteristics of the respondents in this study were nurses with the majority being female and the average age was middle adulthood. The majority of respondents are Acehnese and most of the respondents have a DIII nursing education background and have worked for more than 5 years. All respondents in this study have attended various kinds of training, the majority of research respondents attended MPKP (Professional Nursing Practice Model) training.

Nurses who became respondents in this study already had a good level of knowledge. Nurses already know about schizophrenia including understanding, signs and symptoms to management in schizophrenic patients. Likewise with the level of patient care, based on the results of the study the majority of nurses have provided good care for patients, especially schizophrenia. Based on statistical test analysis of the relationship between nurses' knowledge about schizophrenia and the care of schizophrenic patients in the BLUD. Aceh Mental Hospital Banda Aceh obtained p-value $(0.003)<(0.05)$ this means $\mathrm{Ha}$ is accepted. So it can be concluded that there is a relationship between nurses' knowledge about schizophrenia and the care of schizophrenic patients in the BLUD. Aceh Mental Hospital Banda Aceh. 


\section{References}

Aisha. (2006). Knowledge and attitudes of puskesmas nurses towards providing community nursing care to clients in the Stabat work area of Langkat Regency in 2006. Thesis. Not published.

American Psychiatric Association. (2004). Diagnostic and statistical manual of mental disorders (4th ed). DC : American Psychiatric Association.

Arikunto, S. (2010). The research procedure is a practical approach. Jakarta: Rineka Cipta.

Amelia, DR, \& Anwar, Z. (2013). Relapse in schizophrenic patients. Scientific journal of applied psychology. ISSN, 2301-8267, Vol. 1, No. 1. Fac. Psychology-University of Muhammadiyah Malang. pdf

Ambari, PKM (2010). The relationship between family support and social functioning in schizophrenic patients after hospitalization. Essay. Semarang: Fac. Psychology-Diponegoro University.

Azizatunnisa, N., \& Suhartini. (2012). Knowledge and skills of nurses in holistic nursing services at the Indonesian holistic tourist hospital. Journal of nursing studies. Vol. 1, No. 1, p. 148. Pdf.

Barry, PD (1998). Mental health \& mental illnes. (6th ed). Philadelphia: Lippincott-Raven.

Basford, Lynn. (2006). Nursing Theory and Practice; An integral approach to patient care. Jakarta: EGC.

Dahlan, SM (2004). Statistics for medicine and health. Jakarta: Arkans.

Dalami, E. (2009). Nursing care of clients with mental disorders. Jakarta: Trans Info Media.

Dempsey, AP, \& Dempsey, DA (2002). Nursing research. Jakarta: EGC.

Doenges, ME, Townsend, MC, Moorhouse, MF (2006). Psychiatric nursing care plan. Jakarta: EGC.

Davison, GC, Neale, JM, \& Kring, AM (2006). Abnormal Psychology (Ed. 9). Jakarta: PT. King Grafindo Persada.

Davies, T. (1994). Psychosocial factors and relapse of schizophrenia. 309, 353 from http://www. ncbi.nml.nih.90v/pmc/articles/PMC2541203/pdf/bmj00452-007. Pdf

Indonesian Ministry of Health. (2003). General manual; TPKJM (team of builder, influence, and implementer of community mental health). Jakarta: Ministry of Health RI.

Fairus. AA (2012). The level of knowledge of nurses about therapeutic communication in the general inpatient unit at dr. H. Marzoeki Mahdi Bogor. Essay. University of Indonesia.

Fortinash, K., \& Worret, PH (2003). Psychiatric nursing care plans. (4th ed). St. Louis: Mosby.

Hawari, D. (2007). A holistic approach to schizophrenic mental disorders. Jakarta: FK-UI.

Hidayat,AA (2011). Irmansyah. (2006). Prevention and early intervention of schizophrenia. http://64.203.71.11/kompas print/0410/19/ilpeng/1331282.htm.

Isaacs, A. (2004). Mixed study of mental health \& psychiatry nursing. Jakarta: EGC.

Keliat, BA (1992). Family participation in the care of clients with mental disorders. Jakarta: EGC.

MA Sudjana. (2005). Statistical method. Bandung: Tarsito. 
Moscowitz, A. (2011). Schizophrenia, trauma, dissociation, and scientific revolution; Journal of trauma \& dissociation. Retrieved 26 September 2013 from http://www.informaworld.com/term-and-condition-ofaccess.pdf.

Notoatmodjo, S. (2005). Health research methods. Jakarta: Rineka Cipta Notoatmodjo, S. (2010). Health research methodology. Jakarta: Rineka Cipta.

Nurdiana., Syafwani., \& Umbaransyah. (2007). Family participation on the recurrence rate of schizophrenic clients. Scientific journal of nursing health, Vol. 3, No.1. Pdf.

Nursalam. (2003). Concepts and application of nursing science research methodologies; Guidelines for theses, theses, and research instruments. Jakarta: Salemba Medika.

Prabowo, A. (2010). 50\% of schizophrenic patients relapse (relapse). Accessed on 26 September 2013 from http://adhayatmanprabowo.wordpress.com.

Polit., \& Hungler. (1995). Nursing research principle lessons \& methods. Philadelphia: Lippincot.

Rubyana, U. (2012). The relationship between coping strategies and quality of life in symptomatic remission schizophrenia sufferers. Journal of clinical psychology and mental health. Vol, 1, No. 2. Pdf.

Riyadi, S., \& Purwanto, T. (2009). Mental nursing care. Yogyakarta: Graha Ilmu.

Santoso. (2001). The method of a study. Jakarta: Variety of Scripts.

Sastroasmoro., \& Ishmael. (2011). Fundamentals of clinical research methods edition 4. Jakarta: Sagung seto.

Sihaloho, WR (2008). The relationship between the level of knowledge about client management and the work stress of nurses in the inpatient ward of the Medan Provincial Government Mental Hospital. Essay. Not published.

Sugiyono. (2012). Educational research methods; Quantitative, qualitative, and R\&D approaches. Bandung: Alphabet.

Setiadi, Al (2006). Schizophrenia; Understand the patient's family dynamics. Bandung: Refika Aditama.

Sinaga, BR (2007). Schizophrenia \& differential diagnosis. Jakarta: Faculty of Medicine-University of Indonesia.

Tomb, AD (2003). Psychiatry pocket book. Jakarta: EGC.

Unger, R. (2007). Recovery: Why is it being redefined to mean "doing better but still mentally ill"?. Accessed from http://recoveryfromschizophrenia.org.

Videbeck, LS (2008). Psychiatric nursing textbook. Jakarta: EGC

Wahyuni, AS (2011). Medical statistics. Jakarta: Bamboedoea Communication.

Wode, C., \& Tavris, C. (2007). Psychology. Edition 9.

WHO. (2001). The world health report; 2001 mental health. New understanding, new hope. 